\title{
АНАЛІЗ СТРАТЕГІЇ ОДОМАШНЕННЯ, ЗАСТОСОВАНИЙ В УКРАЇНСЬКОМУ ПЕРЕКЛАДІ МУЛЬТФІЛЬМУ «THE SECRET LIFE OF PETS»
}

\begin{abstract}
Анотація. У статті висвітлюеться поняття аудіовізуального перекладу кінотекстів та особливості перекладу таких текстів українською мовою. Варто відзначити, що переклад фільму займае особливе місце у типології аудіовізуального перекладу. Метою статті є розкриття методики аналізу стратегії одомашнення, застосованої у перекладі мультфільму. Матеріалом дослідження послужив скрипт мультфільму „The Secret Life of Pets» («Секрети домашніх тварин»). У статті розглянуто використання стратегії одомашнення на практищі, проаналізувавши попередньо оригінальні діалоги з англомовного мультфільму „The Secret Life of Pets» та україномовний варіанту. В результаті дослідження в українській версії перекладач надае перекладу діалогів більшої афективності. Отже, найбільша складність у перекладі стилістично забарвленої лексики - це пошук сучасних еквівалентів і часто переклад стилістично-забарвленої лексики залежить від розуміння значення слова в контексті.
\end{abstract}

Ключові слова: аудіовізуальний переклад, кінострічка, дублювання, стратегія одомашнення.

Hryniv Yaryna, Romanyshyn Natalia Lviv Polytechnic National University

\section{ANALYSIS OF THE DOMESTIC STRATEGY USED IN THE UKRAINIAN TRANSLATION OF THE CARTOON «THE SECRET LIFE OF PETS»}

Summary. The article covers the concept of audiovisual translation of film texts and features of translation of such texts into Ukrainian. It is worth noting that the translation of the film occupies a special place in the typology of audiovisual translation. The article aims to reveal the method of analysis of the domestication strategy used in the translation of the cartoon. The study was based on the script of the cartoon „The Secret Life of Pets". The article considers the use of domestication strategy in practice, analyzing the previously original dialogues from the English cartoon „The Secret Life of Pets» and the Ukrainian dubbing. Often the context forces us to choose one of the options, then we have to look for a new translation option - contextual replacement when due to the specifics of a particular context, the translator refuses to use existing lexical matching and chooses a translation option for a particular case. As a result of the research in the Ukrainian version, the translator provides the translation of dialogues with greater affectivity. Thus, the greatest difficulty in translating stylistically colored vocabulary is the search for modern equivalents, and often the translation of stylistically colored vocabulary depends on understanding the meaning of the word in context. After analyzing dialogues with stylistically colored language, we concluded that compilers of dictionaries are usually limited to stylistically neutral variants of lexical units, which convey only their general meaning. Therefore, the work of a translator working with text with stylistically colored language is to find an equivalent in the language of translation, which is characterized by approximately the same expressiveness and emotional coloring. Therefore, for a more adequate translation, it is necessary to take into account the video sequence, which contains additional information about the original. When translating a film text, the translator must convey not only syntactic and semantic structures and phraseology, but also functional and pragmatic aspects. In the process of translating a film, the translator faces many tasks. In particular, the choice of strategies and tactics for the reproduction of realities, ambiguous vocabulary, the search for equivalents of different levels, the adaptation of realities to the cultural stereotypes of the viewer, text support, synchronization with the image.

Keywords: audiovisual translation, film, dubbing, domestication strategy.

$\Pi^{2}$ остановка проблеми. Переклад фрільму займає особливе місце у типології аудіовізуального перекладу і залежно від дистриб'ютора (або замовника та місця первинного перегляду); його можна розділити на кінотеатр (на замовлення відповідної кінокомпанії оригіналу для перегляду фрільмів) та телебачення (за замовленням телевізійного каналу для телетрансляції).

Головною відмінністю між усіма типами аудіовізуального перекладу - це об'єкт перекладу, який у перекладі фрільму потрібно зняти як нерозривну едність вербальної та невербальної інформації, що передається через кілька семіотичних систем. Тому ми не можемо назвати обєєтом перекладу сценарії чи текст фільму, оскільки переклад останнього призначений лише для врахування та відтворення вербальної складової на основі написаного тексту [1, с. 240].
Таким чином, переклад фрільму як тип аудіовізуального має такі диференщіальні особливості: наявність двох каналів сприйняття - зорового та слухового, які взаємодіють і доповнюють один одного; переклад зображення на екрані; відсутність у перекладача здатності інтерпретувати поняття, невідомі новій цільовій аудиторії; домінування принципу забезпечення прагматичного едекту [2, с. 375].

Оскільки переклад фрільму займає особливе місце у типології аудіовізуального перекладу і залежно від дистриб'ютора (або замовника та місця первинного перегляду); його можна розділити на кінотеатр (на замовлення відповідної кінокомпанії оригіналу для перегляду фрільмів) та телебачення (за замовленням телевізійного каналу для телетранслящіi). У цьому випадку типи перекладу фрільмів розрізняються: якщо переклад фрільму 
в основному використовується для дубляжу, то для перекладу телевізійних продуктів - як дубляж, так і позаекранний переклад та субтитри [1, с. 11].

Аналіз досліджень і публікацій. Теоретичною базою дослідження послужили роботи вітчизняних та зарубіжних лінгвістів, таких як Плетенецька Ю., Конкульовський В., Орехова О., Лукьянова Т., Малкович Т., Мельник А., Полякова О., Єфрремової М., Райс К. та інших.

Метою пропонованої статті $є$ розкриття методики аналіз стратегії одомашнення, застосований в перекладі фрільмів. Матеріалом дослідження є скрипт мульторільму „The Secret Life of Pets» («Секрети домашніх тварин»).

Виклад основного матеріалу. Давайте розглянемо використання стратегії одомашнення на практиці, проаналізувавши оригінальні діалоги 3 англомовного мультфільму «Секрети домашніх тварин» та україномовний варіант того ж мультфільму. Застосовувалися такі стартегії перекладу: опущення певного елемента, заміна елемента фрункцінальним еквівалентом та використання описового перекладу.

Опрацьовуючи мультфільм, я знайшла такі приклади одомашнення:

\section{Приклад № 1}

\begin{tabular}{|c|c|}
\hline Англійський варіант & Український варіант \\
\hline It's in my head. & $\begin{array}{c}\text { Воно мені вже в печінках } \\
\text { сидить. }\end{array}$ \\
\hline
\end{tabular}

Фраза "It's in my head" перекладається українською мовою як « Воно мені вже в печінках сидить». В українській мові це фразеологізм, що означае «Набридати, ставати нестерпним». Ми можемо побачити, що ці дві фррази не мають абсолютно однакових значень, але в англійській мові це просто вираз, а не ідіома.

\section{Приклад № 2}

\begin{tabular}{|c|c|}
\hline Англійський варіант & Український варіант \\
\hline $\begin{array}{l}\text { It's on the tip } \\
\text { of my tongue. }\end{array}$ & На язиці крутиться. \\
\hline
\end{tabular}

Згідно з Кембриджським словником, ідіома "It's on the tip of my tongue" означае "про сильне бажання сказати щось, спитати про кого-, щонебудь». "Крутиться на язиці» українською - це фрразеологізм, що означає «нездатність отримати слово 3 пам'яті, поєднана 3 частковим пригадуванням та відчуттям, що слово ось-ось вдасться пригадати, коли воно "крутиться на язику". Ці дві фррази є рівноцінними в обох мовах [1].

\section{Приклад № 3}

\begin{tabular}{|c|c|}
\hline Англійський варіант & Український варіант \\
\hline Three leagues. & Десять кілометрів. \\
\hline
\end{tabular}

Ліга - це одиниця виміру довжини. Ця одиинщя виміру була поширеною в Свропі та Латинській Америщі, але більше не є офріційною одиницею жодної нації. Це слово спочатку означало відстань, яку людина могла пройти за годину. Як і миля, існуе різниця між морською та сухопутною лігами. У перекладі слово «ліга» було одомашнено, оскільки в Україні є інша одиниця вимірювання довжини (кілометр).
Приклад № 4

\begin{tabular}{|c|c|}
\hline Англійський варіант & Український варіант \\
\hline You really nailed him & Ну викапаний він \\
\hline
\end{tabular}

У дуже недрормальних, невимушених розмовах ви можете почути цей вираз. «To nail someone» буквально означає «змалювати когось», тому його переклали українською як «викапаний». Це означає «Дуже схожий на кого-небудь; такий самий, як хтось ". Тут ми бачимо, що оригінальний текст має те саме значення, що і переклад.

\section{Приклад № 5}

\begin{tabular}{|c|c|}
\hline Англійський варіант & Український варіант \\
\hline You can't see a thing. & Хоч в око стрель \\
\hline
\end{tabular}

В українській мові ми використовуемо фрразеологізм "хоч в око стріль», що означає "зовсім нічого не видно, дуже темно». Це дуже точний переклад оригінальної фрази. В українській мові він широко використовуеться у творах різних авторів, таких як Є. Гуцало, П. Мирний, С. ГулакАртемовський та інші [1].

\section{Приклад № 6}

\begin{tabular}{|c|c|}
\hline Англійський варіант & Український варіант \\
\hline $\begin{array}{c}\text { Must have left your } \\
\text { present in the car, sweetie. }\end{array}$ & $\begin{array}{c}\text { Я забув твій подарунок } \\
\text { в машині, пташечко. }\end{array}$ \\
\hline
\end{tabular}

В англійській мові ми часто використовуємо "sweetie" для позначення когось, кого ви любите, наприклад, дитини, партнера, хорошого друга чи наших домашніх тварин. Українське " $n$ maшечко" є аналогом англійського. Тому ми бачимо, що його переклали не як «солоденька, цукерочко», а через стратегію одомашнення.

\section{Приклад № 7}

\begin{tabular}{|c|c|}
\hline Англійський варіант & Украӥнський варіант \\
\hline Cotcha! & Бувай здоровий! \\
\hline
\end{tabular}

В українській мові є традиційні формули побажань, привітань, запрошень. Багато 3 них мають риси фразеологізмів. Їх завдання - за допомогою слів викликати необхідні дії, нав'язати комусь свою волю. Одиниці цього типу міцно пов'язані з національною символікою.

Відтворюючи фрагмент історії культури, вони демонструють національний характер, оскільки генетично пов'язані з традиціями народу, його переконаннями і забобонами, ритуалами та діями тощо. "Бувай здоровий» - це «доброзичливі побажання будь-кому», особливо на прощання. Відповідно до Urban Dictionary, "cotcha" можна визначити як остаточне "goodbye". Це походить від виразу "Chat ya", або "chat to you". Можна зробити висновок, що ці два вирази еквівалентні один одному [35].

\section{Приклад № 8}

\begin{tabular}{|c|c|}
\hline Англійський варіант & Український варіант \\
\hline Come on, Peach! & Давай, зіронько. \\
\hline
\end{tabular}

Українською мовою “зіронько» - це ніжне звернення до людини. Воно була одомашнено звичною українською мовою, оскільки "реасh» 
в українській мові не використовується для позначення особи; його можна використовувати лише в особистій справі. Однак для американців це цілком нормальне звернення.

\section{Приклад № 9}

\begin{tabular}{|c|c|}
\hline Англійський варіант & Український варіант \\
\hline Koochi koochi koo. & Утю-тю-тю. \\
\hline
\end{tabular}

Як згадувалося у міському словнику, «kоосhi koochi koо" використовуеться як сленг для слова "my lover", що найчастіше вживаеться, коли дівчина жартома згадуе свого хлопщя чи найкращого друга. Щодо “Утю-тю-тю», то українською це слово (точніше, просто вигук) означає своєрідне чуттєве i зворушливе вираження своїх почуттів до когось (чи чогось). Наприклад, його можна вигукувати до чарівної дитини, а частіше - коли бачиш цуценя, кошеня чи милу плюшеву дитячу іграшку [35].

\section{Приклад № 10}

\begin{tabular}{|c|c|}
\hline Англійський варіант & Украӥнський варіант \\
\hline We're about to hit it. & Беру на таран. \\
\hline
\end{tabular}

"Йти (брати) на таран" означае нанести сильний, рішучий удар. "To hit» - найкращий варіант для цього перекладу. Фраза англійською мовою описуе значення українського виразу в перекладі.

\section{Приклад № 11}

\begin{tabular}{|c|c|}
\hline Англійський варіант & Український варіант \\
\hline Until they're beating up & Поки ви разом не дасте \\
dozens of animals on the & поганцям добрячого \\
Brooklyn Bridge? & прочухана. \\
\hline
\end{tabular}

За даними Українського фразеологічного словника, "дати прочухана" означае "дуже лаяти, сварити кого-будь». В оригіналі ми маємо dppaзy "beating-up», що означае "насильницький напад, під час якого жертва отримуе неодноразовий удар». Обидва вирази мають невелику різницю у своєму значенні. Вираз "дати прочухана" існуе лише в українській мові і в більшості вживається у літературі.

\section{Приклад № 12}

\begin{tabular}{|c|c|}
\hline Англійський варіант & Украӥнський варіант \\
\hline $\begin{array}{c}\text { You`re in love. How gross } \\
\text { for everyone. }\end{array}$ & Ви сі подивіт! Чи не \\
гаютьсі, не встидаютьсі.
\end{tabular}

Частина "сі» зазвичай використовуеться окремо в західних областях України, хоча вона не кодифікована в літературній мові. Як і багато інших діалектних форм, це стало явною ознакою сільської спільності. Тобто, серйозно, без іронічних наслідків, так говорять лише літні люди або жителі села. Якщо ви чуєте це від мешканців міста чи молоді, це означає, що вони жартують або намагаються зробити свою промову іронічною. "Gross" означає "грубо або образливо, вкрай неприєлно", і це значення пов'язане з його українським перекладом. Приклад ілюструе випадок, коли перекладач фільмів повинен звернути особливу увагу на те, що відбувається на екрані, щоб правильно перекласти, оскільки в цьому випадку практично немає контексту.

\section{Приклад № 13}

\begin{tabular}{|c|c|}
\hline Англійський варіант & Український варіант \\
\hline It is on, humans! & Людиняку на гіляку! \\
\hline
\end{tabular}

Домашні тварини, які ненавидять людей і мріють здійснити революцію з гаслом "Man on a branch" ("людиняку на гіляку»). На сцені вони кричали "It is on, humans!», що буквально означає "вже почалося". Українською мовою вираз "Людиняку на гіляку!" неодноразово вживався у різних суперечках. Це суто український вираз. В українській версії перекладач надав цьому реченню більшої афективності. Це вигук, який рідко використовуеться в повсякденному житті, але знову ж таки виконуе фрункцію створення українського духу та змушуе глядачів думати, що вони дивляться українське, а не американське кіно.

\section{Приклад № 14}

\begin{tabular}{|c|c|}
\hline Англійський варіант & Український варіант \\
\hline Mr. Bossy. & Командуе він. \\
\hline
\end{tabular}

Перш за все, я хотіла би відзначити, що "Mr.» мабуть, буде незрозуміло для дітей, особливо для українщів. Крім того, "Mr" змінили на "він», щоб пояснити це маленьким глядачам. Mr. Bossy походить від слова "бос", що згідно зі словником означає особу, яка здійснює контроль або повноваження [34].

\section{Приклад № 15}

\begin{tabular}{|c|c|}
\hline Англійський варіант & Український варіант \\
\hline It could ingest us. & $\begin{array}{c}\text { Від нас і кісток } \\
\text { не залишиться. }\end{array}$ \\
\hline
\end{tabular}

Український вираз "i кісток не лишити» означає, що хтось повністю розбитий, знищений. "To ingest" означае "випити або з їсти шонебудъ». У цьому випадку він вживається у переносному значенні. Тут ми можемо спостерігати еквівалентність між оригіналом та перекладом.

\section{Приклад № 16}

\begin{tabular}{|c|c|}
\hline Англійський варіант & Український варіант \\
\hline Course you are. & Ще б пак! \\
\hline
\end{tabular}

"Ще б пак" - це український вираз, який вживається для ствердження чого-небудь; інакше й бути не може. Ви вживаєте його, щоб припустити, що щось нормальне, очевидне чи добре відоме, і тому не повинно дивувати людину, з якою ви спілкуєтесь. Тут ми спостерігаємо випадок, коли приручення використовуеться для того, щоб конотація була еквівалентна одна одній [2].

\section{Приклад № 17}

\begin{tabular}{|c|c|}
\hline Англійський варіант & Український варіант \\
\hline Unless it's covered & Хіба якщо їх запхнуть \\
in peanut butter. & в свіженьку сметанку. \\
\hline
\end{tabular}

Згідно з Кембриджським словником, «арахісове мисло» - це м'яка блідо-коричнева паста, зроблена $з$ подрібненого смаженого арахісу, яку часто намазують на хліб. В українському перекладі "арахісове масло" було одомашнено як "слетана». Тому що в Україні люди часто годують своїх улюбленців сметаною, і це звично для нас [3]. 
Найбільша складність при перекладі стилістично забарвленої мови з іноземної мови на мову перекладу і навпаки полягає в тому, що стилістично забарвлена мова-це найбільш рухомий шар словникового запасу, і жоден словник нових слів не може наздогнати розвиток мови в щій галузі. Крім того, багато лексичних одиниць стилістично забарвленої мови є дуже нетривалими та швидко застарілими. Отже, найбільша складність у перекладі стилістично забарвленої лексики - це пошук сучасних еквівалентів [1, p. 13].

Вибір засобів вираження мовою перекладу безпосередньо залежить від розуміння значення слова в контексті. Остаточний варіант перекладу повинен передавати не лише змістовні відтінки слова, а й виразну та стилістичну забарвленість слова.

Часто контекст змушуе вибрати один із варіантів відповідності, тоді доводиться шукати новий варіант перекладу - контекстуальну заміну, коли через специфіку конкретного контексту перекладач відмовляеться використовувати існуючу лексичну відповідність і вибирає варіант перекладу для конкретного випадку [7, с. 18].

Проаналізувавши цей зразок стилістично забарвленої мови, ми прийшли до висновку, що укладачі словників зазвичай обмежуються стилістично нейтральними варіантами лексичних одиниць, які передають лише їх загальне значення. Тому робота перекладача, що працюе 3 текстом із стилістично забарвленою мовою, знайти еквівалент у мові перекладу, яка характеризуеться приблизно однаковою виразністю та емоційним забарвленням.

Таким чином, на основі аналізу вибірки була відзначена закономірність. Взявши $100 \%$ загальної кількості лексичних одиниць у вибірці, ми ді- йшли висновку, що основним способом перекладу стилістично забарвленої лексики $є$ аналог, що становить $47 \%$ від загальної кількості слів. Усі інші лексичні одиниці перекладено з використанням пропусків та еквівалентів. Таким чином, $32 \%$ стилістично забарвлених слів було перекладено еквівалентом, $21 \%$ стилістично забарвленої мови переклали опущенням, проте описового способу перекладу не було виявлено взагалі.

Висновки. У процесі перекладу фільму перед перекладачем стоїть багато завдань. Зокрема, вибір стратегій і тактик для відтворення реалій, двозначна лексика, пошук еквівалентів різних рівнів, адаптація реалій до культурних стереотипів глядача, текстовий супровід, синхронізація із зображенням. Синхронізація із зображенням призведе до скорочення фраз з урахуванням соціального статусу, культурного рівня та віку персонажів, відтворення специфічного гумору, сленгу, перекладу назв фільмів.

Працюючи з кінотекстом, фахівець обирае стратегію перекладу відповідно до цільової аудиторії та художнього стилю автора, а також жанрової специфіки. При перекладі фрільму важливо зберегти оригінальну ідею автора, розкрити героїв. Перекладач повинен якомога точніше та адекватніше передавати інформаційно-емоційне повідомлення, відтворене у словесному мовленні акторів, тексті, що озвучуеться, пісня та титрах [3, с. 118].

Для більш адекватного перекладу необхідно враховувати відеопослідовність, яка містить додаткову інформацію про оригінал. При перекладі кінотексту перекладач повинен передавати не лише синтаксичні та семантичні структури та фразеологізми, але також функціональні та прагматичні аспекти.

\section{Список літератури:}

1. Демецька В., Федорченко О. До проблеми перекладу кінотекстів. Науковий вісник Херсонського державного університету. 2010. С. 239-243.

2. Козуляев А.В. Аудиовизуальный полисемантический перевод как особая форма переводческой деятельности. Царскосельские чтения. 2013. С. 374-381.

3. Anderman G. Audiovisual Translation: Language Transfer on Screen / G. Anderman, J. Diaz-Cintas. 2009. 272 p.

4. Koller W. The Concept of Equivalence and the Object of Translation Studies [Text] / W. Koller. 1995, Target (1(2). P. 191-222.

5. Orero P. Topics in audiovisual translation [Text] / P. Orero. Amsterdam : John Benjamins Pub., 2004.76 p.

6. Paquin, R. Translator, Adapter, Screenwriter. Translating for the audiovisual [Text] / R. Paquin // Translation Journal. 1998. Vol. 2.

7. Szarkowska A. The Power of Film Translation [Text] // Translation Journal. 2009. № 30.

\section{References:}

1. Demetska V. (2010) Do problemy perekladu kinotekstiv [To the problem of translating film texts]. Naukovyi visnyk Khersonskoho derzhavnoho universytetu, pp. 239-243. (in Ukrainian)

2. Kozulyaev A.V. (2013) Audiovizual'nyy polisemanticheskiy perevod kak osobaya forma perevodcheskoy deyatel'nosti [Audiovisual polysemantic translation as a special form of translation activity]. Tsarskosel'skie chteniya, pp. 374-381. (in Russian)

3. Anderman G. (2009) Audiovisual Translation: Language Transfer on Screen / G. Anderman, J. Diaz-Cintas. 272 p.

4. Koller W. (1995) The Concept of Equivalence and the Object of Translation Studies [Text] / W. Koller, Target (1(2), pp. 191-222.

5. Orero P. (2004) Topics in audiovisual translation [Text] / P. Orero. Amsterdam: John Benjamins Pub., 76 p.

6. Paquin R. (1998) Translator, Adapter, Screenwriter. Translating for the audiovisual [Text] / R. Paquin // Translation Journal, vol. 2.

7. Szarkowska A. (2009) The Power of Film Translation [Text] // Translation Journal, no. 30. 